\title{
Eph receptors as therapeutic targets in glioblastoma
}

\author{
B W Day ${ }^{*}, 1$ B W Stringer ${ }^{1}$ and A W Boyd ${ }^{1,2}$ \\ ${ }^{1}$ Brain Cancer \& Leukaemia Foundation Research Unit, QIMR Berghofer Medical Research Institute, Brisbane 4006, \\ Australia and ${ }^{2}$ Department of Medicine, University of Queensland, Herston, Brisbane 4006, Australia
}

The dismal outlook for patients with the most aggressive and common form of adult brain cancer, glioblastoma (GBM), motivates a search for new therapeutic strategies and targets for this aggressive disease. Here we review the findings to date on the role of Eph family receptor tyrosine kinases and their ephrin ligands in brain cancer. Expression of the Eph family of cell surface proteins is generally downregulated to very low levels in normal adult tissues making them particularly attractive for directed therapeutic targeting. Recent Eph targeting studies in pre-clinical models of GBM have been very encouraging and may provide an avenue to treat these highly refractory aggressive tumours.

Eph receptor primary function occurs during early development, where these proteins regulate many cellular processes including adhesive and repulsive mechanisms, mediated by the ability of Eph receptor signalling pathways to regulate key molecules involved in cell motility and adhesion. Although most extensively characterised for their roles in development, Eph receptors and ephrin ligands are re-expressed in a variety of diseases including a number of human malignancies (Pasquale, 2010). Dysregulated cellular de-adhesion and abnormal cytoskeletal functions affecting cell shape and motility are key features of advanced cancers. Eph and ephrins regulate many of these key cellular processes, enabling them to promote tumour invasion and metastasis. The challenge of identifying new targeted therapies with efficacy in GBM is immense. GBMs are the most common malignant primary adult brain cancer and are typically highly aggressive, infiltrative and resistant to conventional therapies. At present treatment involves surgical resection, post-operative radiation and temozolomide chemotherapy (Wen and Kesari, 2008). These treatments are rarely curative, median survival is $<15$ months with only about $10 \%$ of patients surviving for two years without disease recurrence (Stupp et al, 2005).

\section{EPH AND EPHRIN EXPRESSION AND FUNCTION IN GBM}

Introduction. Numerous studies have analysed Eph receptor expression in GBM in seeking to shed light on how this family of receptors might function to promote malignant progression of this disease (Table 1). The accumulated data have led to a better understanding of Eph and ephrin expression levels; despite these efforts very little has been elucidated regarding Eph/ephrin function in GBM. In addition many of these studies were performed prior to recent seminal advances in the neuro-oncology field, defining GBM tumour heterogeneity, molecular subtypes and the identification of putative glioma stem cells (GSCs), which are now thought to be responsible for tumour initiation and recurrence (Vescovi et al, 2006; Verhaak et al, 2010; Brennan et al, 2013). Many of these studies have been performed using long established, serum grown, immortalised cell lines that we now know are no longer representations of the original tumour. In part due to attempts to overcome these limitations, recent larger studies conducted by ourselves and others have started to define Eph function in GBM, with encouraging results.

EphA/ephrin-A family members. Eph receptors have been shown to have somewhat perplexing dichotomous roles with both tumour suppressor and tumour promoting functions being described. This phenomenon stems from the fact that Eph-ephrin complexes can initiate both 'forward' Eph-mediated and 'reverse' ephrin-mediated signalling cascades while receptor-ligand interactions may occur both in cis and in trans with opposing outcomes. Although there are specific examples that run counter to this argument, by and large it appears that EphA receptors, while being highly expressed in many cancers, are relatively kinase-inactive due to either kinase inactivating mutations or low ligand expression (Pasquale, 2010). Indeed, kinase-activated forward signalling tends to inhibit

*Correspondence: Dr BW Day; E-mail: bryan.day@qimrberghofer.edu.au

Received 12 December 2013; revised 15 January 2014; accepted 16 January 2014;

published online 21 August 2014

(C) 2014 Cancer Research UK. All rights reserved 0007 - 0920/14

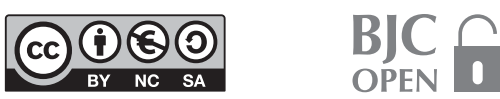




\begin{tabular}{|c|c|c|c|c|}
\hline & Expression & $\begin{array}{l}\text { Clinical } \\
\text { outcome }\end{array}$ & Mechanism & Reference \\
\hline \multicolumn{5}{|c|}{ EphA/ephrin-A } \\
\hline EphA2 & $\begin{array}{l}\uparrow \text { MES/CLAS } \\
\text { subtypes }\end{array}$ & $\begin{array}{l}\text { Poorer } \\
\text { outcome }\end{array}$ & $\begin{array}{l}\uparrow \text { On GSCs/negatively regulates MAPK PW/ligand dependent } \\
\text { and independent roles/effects proliferation, invasion and } \\
\text { neovascularization/loss induces differentiation/Akt Phos EphA2 } \\
\text { at S897/targeting shows proven anti-tumour responses }\end{array}$ & $\begin{array}{l}\text { Binda et al, 2012; Liu et al, 2006; } \\
\text { Wykosky et al, 2005, 2007, 2008a, 2008b; } \\
\text { Liu et al, 2007; Hatano et al, 2005; } \\
\text { Wang et al, 2008a; Li et al, 2007, 2010, } \\
\text { Miao et al, } 2009\end{array}$ \\
\hline EphA3 & $\begin{array}{l}\uparrow \text { MES/CLAS } \\
\text { subtype }\end{array}$ & $\begin{array}{l}\text { Poorer } \\
\text { outcome }\end{array}$ & $\begin{array}{l}\uparrow \text { On GSCs/negatively regulates MAPK PW/proven ligand } \\
\text { independent roles/effects proliferation/loss induces } \\
\text { differentiation/targeting shows proven anti-tumour responses/ } \\
\text { functional mutants identified }\end{array}$ & Day et al, 2013; Wykosky et al, 2007 \\
\hline EphA4 & $\uparrow$ & & $\begin{array}{l}\uparrow \text { In U251 cells affects proliferation and invasion through } \\
\text { EphA4-FGFR1 signalling PW }\end{array}$ & Fukai et al, 2008; Wykosky et al, 2007 \\
\hline EphA5 & Detectable & $\begin{array}{c}\text { Better } \\
\text { outcome }\end{array}$ & $\begin{array}{l}\text { No proven effect on proliferation in U118 cells/expressed in } \\
\text { dormant GBM/downregulated as tumour advances/may have } \\
\text { anti-angiogenic roles }\end{array}$ & $\begin{array}{l}\text { Bruce et al, 1999; Almog et al, 2009; } \\
\text { Wykosky et al, } 2007\end{array}$ \\
\hline EphA7 & $\uparrow$ & $\begin{array}{l}\text { Poorer } \\
\text { outcome }\end{array}$ & Correlation with microvascular density & Wang et al, 2008b \\
\hline EphA8 & $\downarrow$ & & $\begin{array}{l}\text { Induces neuronal-like differentiation in rat glioma cells by } \\
\text { inducing sustained MAPK activation }\end{array}$ & Gu et al, 2007 \\
\hline Ephrin-A1 & $\downarrow$ & & $\begin{array}{l}\text { Negative regulator of EphA2/forced expression attenuates } \\
\text { adhesion, migration and proliferation }\end{array}$ & Hatano et al, 2005; Liu et al, 2007 \\
\hline Ephrin-A5 & $\downarrow$ & & $\begin{array}{l}\text { Tumour suppressive role via negative regulation of EGFR/ } \\
\text { downregulated in glioma }\end{array}$ & Li et al, 2009 \\
\hline \multicolumn{5}{|c|}{ EphB/ephrin-B } \\
\hline EphB2 & $\uparrow$ & & $\begin{array}{l}\text { Dichotomous role suggested where } \uparrow \text { EphB2 increases } \\
\text { migration and invasion while decreases proliferation/function } \\
\text { mediated via R-Ras and FAK signalling/targeted by miR-204/ } \uparrow \\
\text { during GBM differentiation }\end{array}$ & $\begin{array}{l}\text { Nakada et al, 2004, 2005; Wang et al, 2012; } \\
\text { Ying et al, } 2013\end{array}$ \\
\hline EphB4 & $\uparrow$ & $\begin{array}{l}\text { Poorer } \\
\text { outcome }\end{array}$ & $\begin{array}{l}\text { Promotes angiogenesis (venous) via the DLL-4-Notch signalling } \\
\text { PW/co-expressed with ephrin-B2/ } \\
\uparrow \text { EphB4 correlates with increasing tumour grade/activates } \\
\text { EGFR signalling to promote growth/mutated at low frequency / } \\
\uparrow \text { on less-differentiated cells }\end{array}$ & $\begin{array}{l}\text { Tu et al, 2012; Li et al, 2011; Li et al, 2012; } \\
\text { Xiao et al, 2004; Chen et al, 2013; } \\
\text { Erber et al, } 2006\end{array}$ \\
\hline EphB6v & $\uparrow$ & & $\begin{array}{l}\text { EphB6 variant lacking transmembrane and cytoplasmic } \\
\text { domains/ } \uparrow \text { in GBM cell lines/two unique antigenic peptide } \\
\text { sequences of EphB6v were recognised by CTL in a HLA-A24 } \\
\text { restricted manner/potential targets for immunotherapy }\end{array}$ & Jin et al, 2008 \\
\hline Ephrin-B1 & & & Expression promotes invasion in U87-MG cells & Nakada et al, 2010 \\
\hline Ephrin-B3 & $\uparrow$ & $\begin{array}{l}\text { Poorer } \\
\text { outcome }\end{array}$ & $\begin{array}{l}\uparrow \text { ephrin-B2 correlates with increasing tumour grade/co- } \\
\text { expressed with EphB4/regulates tumour angiogenesis (arterial) } \\
\text { via VEGFR regulation/phosphorylation promotes cell migration } \\
\text { and invasion/ } \uparrow \text { on less-differentiated cells } \\
\text { Promotes cell invasion through activation of Rac1 }\end{array}$ & $\begin{array}{l}\text { Tu et al, 2012; Nakada et al, 2010; } \\
\text { Sawamiphak et al, 2010; Li et al, 2011; } \\
\text { Li et al, 2012; Xiao et al, 2004; } \\
\text { Erber et al, 2006 } \\
\text { Nakada et al, 2006, } 2010\end{array}$ \\
\hline
\end{tabular}

Abbreviations: $\uparrow=$ upregulated; $\downarrow=$ downregulated; Akt = protein kinase $B$; CLAS = classical subtype; CTL=cytotoxic T-lymphocyte; DLL=delta-like ligand; EGFR=epidermal growth factor receptor; $F A K=$ focal adhesion kinase; FGFR=fibroblast growth factor receptor; GSC=glioma stem cell; HLA=human leukocyte antigen; MAPK= mitogen-activated protein kinase; $\mathrm{MES}=$ mesenchymal subtype; $\mathrm{miR}=$ microRNA; Notch = neurogenic locus notch homologue protein; Phos = phosphorylation; PW = pathway; R-Ras = ras-related protein; Rac = ras-related C3 botulinum toxin substrate; VEGFR = vascular endothelial growth factor receptor.

proliferation and cell migration leading to decreased invasiveness of cancer cells. This idea appears to hold true in the case of GBM, recent findings suggest that EphA receptors are expressed in a gradient with high expression present on the more aggressive GSC mesenchymal phenotype. Conversely elevated ephrin-A expression correlates with a less-aggressive more-differentiated phenotype with a better patient prognosis (Figure 1). This has been well demonstrated for both EphA2 and EphA3 and their high affinity ligands ephrin-A1 and ephrin-A5, respectively (Wykosky et al, 2005; Liu et al, 2007; Wykosky et al, 2008b; Li et al, 2009, 2010; Binda et al, 2012; Day et al, 2013). The most widely studied EphA receptor to date has been EphA2 that has been shown to be highly expressed in GBM specimens but not in normal brain (Wykosky et al, 2005). EphA2 has also been found to be highly expressed on the tumour vasculature in GBM suggesting a role in neovascularisation (Wu et al, 2011). Moreover increased EphA2 expression has been correlated with pathological grade, proliferation and apoptosis in astrocytic brain tumours (Li et al, 2007). EphA2 overexpression has been shown to inversely correlate with GBM patient survival (Liu et al, 2006; Wang et al, 2008a). The high affinity EphA2 ligand, ephrin-A1, is lowly expressed in GBM especially in areas of EphA2 positivity (Hatano et al, 2005; Liu et al, 2007). Overexpression of ephrin-A1 was shown to downregulate both EphA2 and focal adhesion kinase (FAK) 
leading to reduced migration, adhesion and proliferation of GBM cells (Liu et al, 2007). The preferred ligand for EphA3, ephrin-A5, has also been reported to be expressed at low levels in GBM and has been proposed as a tumour suppressor through its negative regulation of EGFR. Evidence shows a mutually exclusive expression pattern of ephrin-A5 and EGFR. It was shown that ephrin-A5 enhanced c-Cbl binding to EGFR, thus promoting ubiquitination and degradation of the receptor (Li et al, 2009).

Recent studies of EphA2 and EphA3 in GBM have shown that both receptors are expressed most highly on the cells responsible for tumour formation and were also found to be co-expressed with other reported GSC markers such as CD133 and integrin $\alpha 6$ (Binda et al, 2012; Day et al, 2013). In addition, these studies, using the TCGA database, showed differential expression of both EphA2 and EphA3 in molecular subtypes of GBM. Greatest expression was present in the most aggressive, de-differentiated, stem cell-like mesenchymal subtype, although elevated expression was also detected in the EGFR-driven classical subtype. These receptors, despite being relatively kinase-inactive in GBM, are not silent passengers, but through kinase-independent signalling, contribute to the malignant process. Functionally it appears that this is in part mediated through cross talk with growth factor receptors and adhesion molecules, such as integrins and cadherins, to promote angiogenesis, tumour cell proliferation and to support formation of the tumour microenvironment. Both EphA2 and EphA3 were shown to actively maintain GBM cells in a stem-like state by negatively regulating the MAPK pathway. Sustained ERK1/2 signalling was observed following knockdown of either EphA2 or EphA3, leading to increased GBM cell differentiation and reduced tumorigenic potential in GBM xenograft models (Binda et al, 2012; Day et al, 2013). These findings were at first counterintuitive given that the differentiated EphA2/A3-low GBM cells proliferated significantly slower than in EphA2/A3-high GSCs, in which the MAPK pathway was only transiently activated. However, these findings fit with the observations of others showing that sustained MAPK activation mediated via the EphA8 receptor also led to neuronal differentiation ( $\mathrm{Gu}$ et al, 2005). This idea, that transient versus sustained MAPK signalling can drive either proliferation or differentiation is not new (Marshall, 1995). It appears that the outcome of either proliferation or differentiation depends highly upon the duration of ERK activation and cell context. In the context of neuronal cells and GBM, receptor tyrosine kinases such as EphA2 and EphA3 appear to act as switches to regulate the duration of ERK activation and subsequent ability of these cells to undergo differentiation. Cues from the microenvironment and

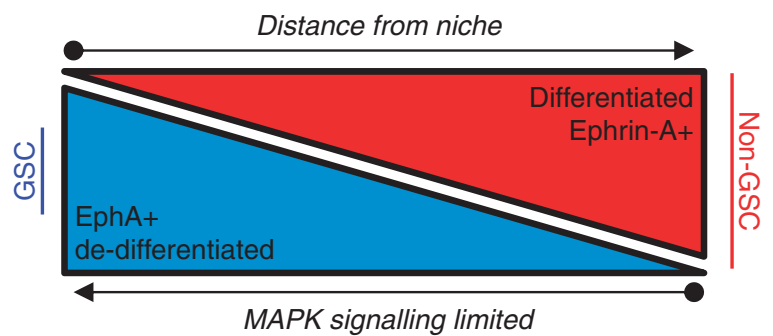

Figure 1. Model of EphA/ephrin-A expression in GBM. A model has emerging suggesting that EphA receptors and ephrin-A ligands may exist within an expression gradient in GBM. EphA receptor expressing cells are poorly activated due to low ligand expression and take on a more de-differentiated mesenchymal-like GSC phenotype, whereas elevated ephrin-A expression led to a less-aggressive moredifferentiated epithelial phenotype. Functionally, EphA receptors appear to maintain this GSC phenotype by limiting the duration of MAPK signalling. Cues from the microenvironment and proximity to niche may also be critical in this process; EphA receptor expression diminishes as tumour cells expanded away from the vascular niche. proximity to niche may also be critical; we observed elevated EphA3 staining immediately around the vascular niche in GBM, expression rapidly decreased as cells expanded away from tumour blood vessels (Figure 1).

Several studies have reported expression of other EphA receptors in GBM, although less has been described functionally in these reports. EphA4 was shown to be overexpressed in GBM tissue and analysis of EphA4 in the U251 GBM cell line showed that EphA4 formed a complex with FGFR1 and that this association increased FGFR downstream signalling leading to increased proliferation and migration (Fukai et al, 2008). EphA5 was also shown to be overexpressed in some astrocytomas and GBM, although functional activation of the receptor was not found to promote cell proliferation in the GBM cell line U118 (Bruce et al, 1999). Another study found loss of EphA5 in plasma correlated with increased tumour grade in glioma patients, and that this protein could be used as a novel biomarker in GBM (Almog et al, 2009). EphA7 has also been reported to be highly expressed in GBM and was a predictor of poor clinical outcome (Wang et al, 2008b). Interestingly in the absence of ligand activation, EphA8 induced neuronal differentiation in rat glioma cells by inducing sustained MAPK activation ( $\mathrm{Gu}$ et al, 2005).

EphB/ephrin-B family members. EphB/ephrin-B signalling appears to differ from that of EphA/ephrin-A proteins. Indeed the function of these receptors is less well characterised in GBM, although it is clear that they do have functional roles in GBM cell migration, invasion and tumour angiogenesis. High levels of EphB2 have been observed in human glioma cells and strong kinase activation of EphB2 has been reported, specifically in migrating U87 GBM cells. Consistent with a role in glioma invasiveness, high levels of EphB2 reduced adhesion and increased GBM cell migration and invasion in vitro and using an ex vivo rat brain slice invasion assay (Nakada et al, 2004). Furthermore this effect was shown to be regulated by R-Ras, a small GTPase implicated as a signal mediator of Eph receptors. EphB2 decreased extracellular matrix adhesion through activation of R-Ras signalling (Nakada et al, 2005). A recent study has shown that miR-204 suppressed both glioma cell migration and reduced stem cell selfrenewal and stem cell-like features, interestingly miR-204 was shown to target the stemness-inducing transcription factor SOX4 and EphB2 (Ying et al, 2013). These invasive effects are not only Eph-mediated, but also appear to be induced by ephrin ligands. Similarly, the EphB ligand, ephrin-B3 is also overexpressed in GBM cell lines and promotes cell migration and invasion via a Rac1-mediated effect (Nakada et al, 2006). Rac1, a small Rho GTPase, has roles in cytoskeletal organisation and plasticity in glioma migration and invasion (Chuang et al, 2004). Furthermore Nakada et al (2010) found that forced expression of ephrin-B2 enhanced migration and invasion and that high ephrin-B2 expression was a strong predictor of shorter survival. A recent finding highlighted an interesting dichotomous role of EphB2 in GBM (Wang et al, 2012). This evidence suggests that although elevated EphB2 increased migration and invasion, it also decreased proliferation in GBM stem-like neurospheres. This was further confirmed by EphB2 silencing, which conversely increased proliferation and decreased migration. The pro-migratory and anti-proliferative effects of EphB2 in GBM are intriguing; this behaviour was documented in GBM cells almost two decades ago showing that proliferation and migration are temporarily mutually exclusive behaviours (Giese et al, 1996). FAK appeared to be critical in this process and was heavily localised in the membrane of non-migrating cells and absent in migrating cells. FAK acts downstream of EphB2 and is a pivotal mediator of EphB2 induced cell migration. FAK and EphB2 have been shown to be co-localised in GBM and FAK pathway inhibitors prevented migration of EphB2 overexpressing cells. Although EphB2 has emerged from 
these studies as a candidate for therapeutic strategies to prevent GBM tumour invasion, one caveat would be that inhibiting EphB2 signalling may also increase GBM cell proliferation.

EphB4 has been shown to be expressed in endothelial cells of embryonic veins while ephrin-B2 is expressed in endothelial cells of arteries, in this instance acting in the guidance and formation of these tissues (Wang et al, 1998). It is not surprising then that EphB4/ephrin-B2 expression has been detected in GBM and linked to tumour angiogenesis (Xiao et al, 2004; Erber et al, 2006; Chen et al, 2013). EphB4 has been shown to promote venous angiogenesis via the DLL-4-Notch signalling pathway (Li et al, 2011, 2012), whereas ephrin-B2 promotes arterial angiogenesis through regulation of VEGFR2 function (Sawamiphak et al, 2010). Expression of these proteins has also been positively correlated with GBM progression and poor prognosis (Tu et al, 2012).

\section{EPH RECEPTORS AS THERAPEUTIC TARGETS IN GBM}

Potential Eph receptor targeting strategies. Several potential therapeutic strategies have emerged to target Eph receptors in cancer (Figure 2). Some approaches aim to activate Eph kinase function through ligand stimulation, activating antibodies or
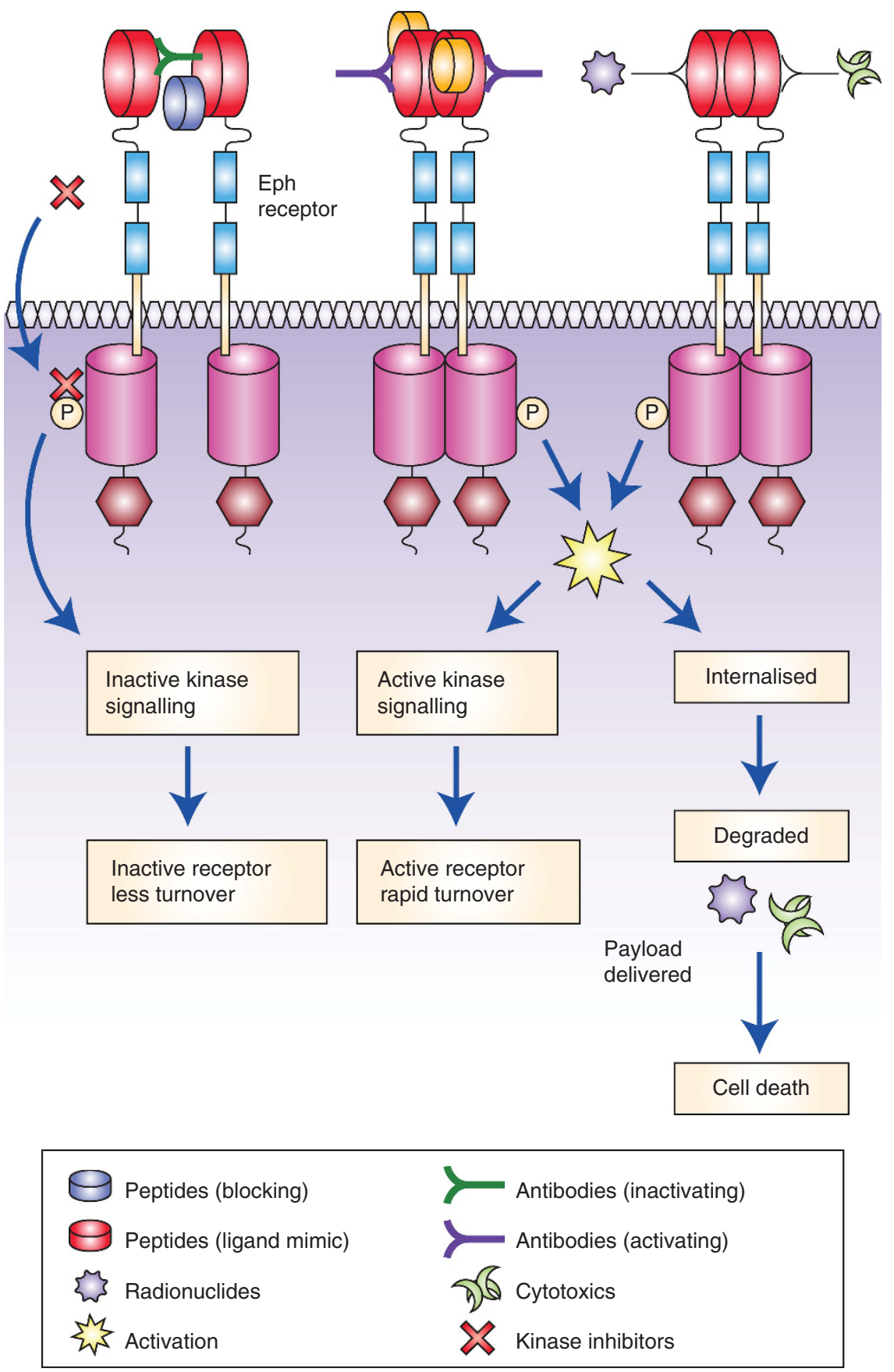

Figure 2. Potential therapeutic strategies to target Eph receptors in GBM. Several approaches exist to target Eph receptors. Kinase inactivating strategies include kinase inhibitors or blocking peptides or antibodies. Kinase-activating strategies include ligand stimulation, activating antibodies or ligand peptide mimetics strategies to deliver toxic payloads following receptor activation and internalisation include coupling of cytotoxic agents or radionuclides to Eph monoclonal antibodies. 
ligand peptide mimetics, these strategies aim to take advantage of Eph forward signalling to induce tumour suppressive functions. In situations where Eph activation leads to tumour promotion, strategies that block active kinase signalling are sought. These typically include kinase inhibitors or the use of ephrin-blocking peptides or antibodies. It is now well established that Eph receptor activation typically leads to rapid internalisation and degradation of receptor complexes. For clinical application protein targets with rapid turnover can be exploited to deliver cytotoxic payloads using antibody drug conjugates (ADCs). The most commonly used ADCs include Maytansine (USAN) and monomethyl auristatin E (MMAE) also known as Vedotin, these are potent antimitotic agents, which inhibit cell division by binding to tubulin and blocking microtubule assembly. Another effective approach is to couple monoclonal antibodies (mAbs) to a radionuclide, which delivers a lethal dose of radiation. Radio-immunotherapies are attractive for a number of reasons: they induce potent killing in aggressive cancers such as GBM and, depending upon the half-life and radiation spectra of the radionuclide chosen, can induce significant 'bystander' effects killing adjacent tumour cells and tumour stromal cells (for a detailed review of Eph receptors as therapeutic targets see (Boyd et al (2013)).

Proven pre-clinical successes. EphA2 has been effectively targeted in GBM animal models using strategies which rely on receptor activation. Studies using treatment with the preferred EphA2 ligand, ephrin-A1 showed that both unlabelled ephrin-A1-Fc (Binda et al, 2012), and ephrin-A1 coupled to the pseudomonas aeruginosa exotoxin (Wykosky et al, 2007, 2008a) were effective. Our recent studies have also shown that targeting the EphA3 receptor using an EphA3 mAb with activating properties coupled to the beta-emitting radionuclide lutetium $\left({ }^{177} \mathrm{Lu}\right)$ was an effective strategy to target both subcutaneous and orthotopic GBM tumourbearing animals with minimal toxicity (Day et al, 2013). Importantly, this antibody binds with equal affinity to both mouse and human EphA3 and no toxicity in normal tissues was observed.

EphA2 has also been investigated as a possible target for novel immunotherapeutic vaccines. A vaccine comprising autologous dendritic cells loaded with a synthetic EphA2 peptide was shown to induce an interferon response and specific cytotoxic T-lymphocyte (CTL) responses in glioma cell lines, highlighting the potential of molecularly targeted glioma vaccines (Hatano et al, 2005). Studies in melanoma patients have shown that EphA3 may be a source of tumour-specific antigens recognised on tumour cells that express HLA class II molecules (Chiari et al, 2000). A variant of EphB6 (EphB6v) was shown to be overexpressed in a panel of brain tumour cell lines (Jin et al, 2008). Interestingly EphB6v has a unique C-terminal 54 amino-acid sequence. Jin et al (2008) generated two antigenic peptides to this region for the purposes of developing an immunotherapeutic agent. The two EphB6v-derived peptides bound HLA-A0201 molecules and were shown to induce CTLs in vitro in the peripheral blood mononuclear cells of HLA-A2 ${ }^{+}$glioma patients.

\section{CONCLUSION}

Defining Eph receptors as therapeutic targets in brain cancer: an evolving field. Recent studies in GBM have greatly strengthened the argument that this family of cell surface proteins are functionally relevant to both the initiation and progression of adult brain cancer and therefore make rational therapeutic targets. Eph receptors are, in general, highly expressed during embryonic development but are downregulated or expressed in a restricted manner in normal adult tissues and thus represent relatively tumour-selective targets. GBM are highly heterogeneous tumours, therefore, it is not surprising that we observe a gradient where
EphA family receptors are expressed on the more de-differentiated stem-like cells and absent on the less-aggressive differentiated tumour tissue. Moreover there is evidence that EphA receptors are expressed in the sub-ventricular zone (SVZ), a known normal brain stem cell niche, and have functional roles in neurogenesis during early brain development (Aoki et al, 2004). Re-expression of EphA receptors on GSCs may indeed echo this role in normal development where Eph proteins function to support niche formation and promote a stem cell phenotype. We show that EphA3 is highly expressed in mesenchymal subtype GBM. Interestingly, during heart development, EphA3 expression, induced by EMT, has a critical role in formation of atrioventricular valves and septa (Stephen et al, 2007). These findings suggest that EphA3 expression may increase as part of the switch to a more mesenchymal phenotype. We observed a robust anti-tumour response in animals treated with an EphA3 mAb conjugated to the radionuclide lutetium, this was combined with very low levels of toxicity. This can most likely be attributed to very low EphA3 expression in normal tissues. These positive animal studies must be interpreted with some degree of prudence, as discussed above; several studies have proposed and tested strategies to target EphA2 in solid tumours in mice with minimal toxicity. However, a recent MedImmune phase 1 clinical trial in solid tumours tested the efficacy of MEDI-547, an EphA2 mAb conjugated to the cytotoxic agent MMAE, the study was stopped due to serious adverse events (AE) including significant pain, liver disorder and haemorrhage (Annunziata et al, 2013). The latter AE most likely attributed to expression of EphA2 on endothelial and hepatic tissues. These AEs may be unique to MEDI-547 or restricted to strategies which target EphA2 positive cells using cytotoxic payloads. Several ongoing vaccine trials targeting, among others, EphA2 have so far proven safe in man; in addition GBM can be treated loco-regionally to limit potential systemic toxicities (Yamaguchi et al, 2008; Debinski and Tatter, 2009; Okada et al, 2011).

Directions for the future. Other EphA receptors such as EphA7, which has been shown to be a predictor of poor clinical outcome in GBM, may also hold significant potential. EphA7 has been shown to be ubiquitously expressed on quiescent ependymal cells and was co-expressed with nestin, a marker associated with neural stem cells (Holmberg et al, 2005). Holmberg et al (2005) describe both ephrin-A2 and EphA7 as negative regulators of neural progenitor cell differentiation. These findings suggest a potential role of EphA7 in promoting GSCs. The discrete expression of EphA7 on ependymal cells is also of interest and may be significant in the maintenance of ependymomas. Eph receptors may also have a functional role in other brain cancers such as medulloblastoma. Only a handful of studies to date have reported Eph receptor expression in these predominantly paediatric tumours, such as a recent meta-analysis which identified EphA3 as a potential therapeutic target (Haeberle et al, 2012).

Eph receptors are often expressed on migrating tumour cells especially at the leading edge where GBM cells are actively invading into the brain parenchyma. This observation has led to the investigation of Eph mAbs as potential imaging agents, which might accurately delineate tumour borders and better define areas of active invasion allowing more complete resection and better patient outcomes (Cai et al, 2007). mAbs against EphB2 are an obvious candidate given the strong link between this receptor and actively migrating GBM cells. Enhanced imaging agents are at present an unmet clinical need in neuro-oncology, this area of Eph related research is still in its infancy and may hold significant potential for the future.

In summary, recent advances in our understanding of Eph receptor biology in GBM has unearthed Eph receptors as genuine therapeutic targets in this disease. This has now been validated 
in pre-clinical studies and early phase clinical testing appears imminent.

\section{CONFLICT OF INTEREST}

The authors declare no conflict of interest.

REFERENCES

Almog N, Ma L, Raychowdhury R, Schwager C, Erber R, Short S, Hlatky L, Vajkoczy P, Huber PE, Folkman J, Abdollahi A (2009) Transcriptional switch of dormant tumors to fast-growing angiogenic phenotype. Cancer Res 69(3): 836-844.

Annunziata CM, Kohn EC, LoRusso P, Houston ND, Coleman RL, Buzoianu M, Robbie G, Lechleider R (2013) Phase 1, open-label study of MEDI-547 in patients with relapsed or refractory solid tumors. Invest New Drugs 31(1): 77-84.

Aoki M, Yamashita T, Tohyama M (2004) EphA receptors direct the differentiation of mammalian neural precursor cells through a mitogen-activated protein kinase-dependent pathway. J Biol Chem 279(31): 32643-32650.

Binda E, Visioli A, Giani F, Lamorte G, Copetti M, Pitter KL, Huse JT, Cajola L, Zanetti N, Dimeco F, De Filippis L, Mangiola A, Maira G, Anile C, De Bonis P, Reynolds BA, Pasquale EB, Vescovi AL (2012) The EphA2 receptor drives self-renewal and tumorigenicity in stem-like tumor-propagating cells from human glioblastomas. Cancer Cell 22(6): 765-780.

Boyd AW, Bartlett PF, Lackmann M (2013) Therapeutic targeting of EPH receptors and their ligands. Nat Rev Drug Discov 13(1): 39-62.

Brennan CW, Verhaak RG, McKenna A, Campos B, Noushmehr H, Salama SR, Zheng S, Chakravarty D, Sanborn JZ, Berman SH, Beroukhim R, Bernard B, Wu CJ, Genovese G, Shmulevich I, Barnholtz-Sloan J, Zou L, Vegesna R, Shukla SA, Ciriello G, Yung WK, Zhang W, Sougnez C, Mikkelsen T, Aldape K, Bigner DD, Van Meir EG, Prados M, Sloan A, Black KL, Eschbacher J, Finocchiaro G, Friedman W, Andrews DW, Guha A, Iacocca M, O’Neill BP, Foltz G, Myers J, Weisenberger DJ, Penny R, Kucherlapati R, Perou CM, Hayes DN, Gibbs R, Marra M, Mills GB, Lander E, Spellman P, Wilson R, Sander C, Weinstein J, Meyerson M, Gabriel S, Laird PW, Haussler D, Getz G, Chin L, Network TR (2013) The somatic genomic landscape of glioblastoma. Cell 155(2): 462-477.

Bruce V, Olivieri G, Eickelberg O, Miescher GC (1999) Functional activation of EphA5 receptor does not promote cell proliferation in the aberrant EphA5 expressing human glioblastoma U-118 MG cell line. Brain Res 821(1): 169-176.

Cai W, Ebrahimnejad A, Chen K, Cao Q, Li ZB, Tice DA, Chen X (2007) Quantitative radioimmunoPET imaging of EphA2 in tumor-bearing mice. Eur J Nucl Med Mol Imaging 34(12): 2024-2036.

Chen T, Liu X, Yi S, Zhang J, Ge J, Liu Z (2013) EphB4 is overexpressed in gliomas and promotes the growth of glioma cells. Tumour Biol 34(1): 379-385.

Chiari R, Hames G, Stroobant V, Texier C, Maillere B, Boon T, Coulie PG (2000) Identification of a tumor-specific shared antigen derived from an Eph receptor and presented to CD4 T cells on HLA class II molecules. Cancer Res 60(17): 4855-4863.

Chuang YY, Tran NL, Rusk N, Nakada M, Berens ME, Symons M (2004) Role of synaptojanin 2 in glioma cell migration and invasion. Cancer Res 64(22): 8271-8275.

Day BW, Stringer BW, Al-Ejeh F, Ting MT, Wilson J, Ensbey KS, Jamieson PR, Bruce ZC, Lim YC, Offenhauser C, Charmsaz S, Cooper LT, Ellacott JK, Harding A, Leveque L, Inglis PL, Allan S, Walker DG, Lackmann M, Osborne G, Khanna KK, Reynolds BA, Lickliter JD, Boyd AW (2013) EphA3 maintains tumorigenicity and is a therapeutic target in glioblastoma multiforme. Cancer Cell 23(2): 238-248.

Debinski W, Tatter SB (2009) Convection-enhanced delivery for the treatment of brain tumors. Expert Rev Neurother 9(10): 1519-1527.

Erber R, Eichelsbacher U, Powajbo V, Korn T, Djonov V, Lin J, Hammes HP, Grobholz R, Ullrich A, Vajkoczy P (2006) EphB4 controls blood vascular morphogenesis during postnatal angiogenesis. EMBO J 25(3): 628-641.

Fukai J, Yokote H, Yamanaka R, Arao T, Nishio K, Itakura T (2008) EphA4 promotes cell proliferation and migration through a novel EphA4-FGFR1 signaling pathway in the human glioma U251 cell line. Mol Cancer Ther 7(9): 2768-2778.

Giese A, Loo MA, Tran N, Haskett D, Coons SW, Berens ME (1996) Dichotomy of astrocytoma migration and proliferation. Int J Cancer 67(2): 275-282.

Gu C, Shim S, Shin J, Kim J, Park J, Han K, Park S (2005) The EphA8 receptor induces sustained MAP kinase activation to promote neurite outgrowth in neuronal cells. Oncogene 24(26): 4243-4256.

Haeberle H, Dudley JT, Liu JT, Butte AJ, Contag CH (2012) Identification of cell surface targets through meta-analysis of microarray data. Neoplasia 14(7): 666-669.

Hatano M, Eguchi J, Tatsumi T, Kuwashima N, Dusak JE, Kinch MS, Pollack IF, Hamilton RL, Storkus WJ, Okada H (2005) EphA2 as a glioma-associated antigen: a novel target for glioma vaccines. Neoplasia 7(8): 717-722.

Holmberg J, Armulik A, Senti KA, Edoff K, Spalding K, Momma S, Cassidy R, Flanagan JG, Frisen J (2005) Ephrin-A2 reverse signaling negatively regulates neural progenitor proliferation and neurogenesis. Genes Dev 19(4): 462-471.

Jin M, Komohara Y, Shichijo S, Harada M, Yamanaka R, Miyamoto S, Nikawa J, Itoh K, Yamada A (2008) Identification of EphB6 variantderived epitope peptides recognized by cytotoxic T-lymphocytes from HLA-A24 + malignant glioma patients. Oncol Rep 19(5): 1277-1283.

Li JJ, Liu DP, Liu GT, Xie D (2009) EphrinA5 acts as a tumor suppressor in glioma by negative regulation of epidermal growth factor receptor. Oncogene 28(15): 1759-1768.

Li JL, Sainson RC, Oon CE, Turley H, Leek R, Sheldon H, Bridges E, Shi W, Snell C, Bowden ET, Wu H, Chowdhury PS, Russell AJ, Montgomery CP, Poulsom R, Harris AL (2011) DLL4-Notch signaling mediates tumor resistance to anti-VEGF therapy in vivo. Cancer Res 71(18): 6073-6083.

Li X, Wang L, Gu JW, Li B, Liu WP, Wang YG, Zhang X, Zhen HN, Fei Z (2010) Up-regulation of EphA2 and down-regulation of EphrinA1 are associated with the aggressive phenotype and poor prognosis of malignant glioma. Tumour Biol 31(5): 477-488.

Li X, Wang Y, Wang Y, Zhen H, Yang H, Fei Z, Zhang J, Liu W, Wang Y, Zhang X (2007) Expression of EphA2 in human astrocytic tumors: correlation with pathologic grade, proliferation and apoptosis. Tumour Biol 28(3): 165-172.

Li ZQ, Gong LL, Wen ZH, Wang J, Xu CS, Huang XD (2012) Delta-like ligand 4 correlates with endothelial proliferation and vessel maturation in human malignant glioma. Onkologie 35(12): 763-768.

Liu DP, Wang Y, Koeffler HP, Xie D (2007) Ephrin-A1 is a negative regulator in glioma through down-regulation of EphA2 and FAK. Int J Oncol 30(4): 865-871.

Liu F, Park PJ, Lai W, Maher E, Chakravarti A, Durso L, Jiang X, Yu Y, Brosius A, Thomas M, Chin L, Brennan C, DePinho RA, Kohane I, Carroll RS, Black PM, Johnson MD (2006) A genome-wide screen reveals functional gene clusters in the cancer genome and identifies EphA2 as a mitogen in glioblastoma. Cancer Res 66(22): 10815-10823.

Marshall CJ (1995) Specificity of receptor tyrosine kinase signaling: transient versus sustained extracellular signal-regulated kinase activation. Cell 80(2): 179-185.

Miao H, Li DQ, Mukherjee A, Guo H, Petty A, Cutter J, Basilion JP, Sedor J, Wu J, Danielpour D, Sloan AE, Cochen ML, Wang B (2009) EphA2 mediates ligand-dependent inhibition and ligand-independent promotion of cell migration and invasion via a reciprocal regulatory loop with Akt. Cancer Cell 16(1): 9-20.

Nakada M, Anderson EM, Demuth T, Nakada S, Reavie LB, Drake KL, Hoelzinger DB, Berens ME (2010) The phosphorylation of ephrin-B2 ligand promotes glioma cell migration and invasion. Int J Cancer 126(5): $1155-1165$.

Nakada M, Drake KL, Nakada S, Niska JA, Berens ME (2006) Ephrin-B3 ligand promotes glioma invasion through activation of Rac1. Cancer Res 66(17): 8492-8500.

Nakada M, Niska JA, Miyamori H, McDonough WS, Wu J, Sato H, Berens ME (2004) The phosphorylation of EphB2 receptor regulates migration and invasion of human glioma cells. Cancer Res 64(9): 3179-3185.

Nakada M, Niska JA, Tran NL, McDonough WS, Berens ME (2005) EphB2/R-Ras signaling regulates glioma cell adhesion, growth, and invasion. Am J Pathol 167(2): 565-576.

Okada H, Kalinski P, Ueda R, Hoji A, Kohanbash G, Donegan TE, Mintz AH, Engh JA, Bartlett DL, Brown CK, Zeh H, Holtzman MP, Reinhart TA, 
Whiteside TL, Butterfield LH, Hamilton RL, Potter DM, Pollack IF, Salazar AM, Lieberman FS (2011) Induction of CD8 + T-cell responses against novel glioma-associated antigen peptides and clinical activity by vaccinations with \{alpha\}-type 1 polarized dendritic cells and polyinosinicpolycytidylic acid stabilized by lysine and carboxymethylcellulose in patients with recurrent malignant glioma. J Clin Oncol 29(3): 330-336.

Pasquale EB (2010) Eph receptors and ephrins in cancer: bidirectional signalling and beyond. Nat Rev Cancer 10(3): 165-180.

Sawamiphak S, Seidel S, Essmann CL, Wilkinson GA, Pitulescu ME, Acker T, Acker-Palmer A (2010) Ephrin-B2 regulates VEGFR2 function in developmental and tumour angiogenesis. Nature 465(7297): 487-491.

Stephen LJ, Fawkes AL, Verhoeve A, Lemke G, Brown A (2007) A critical role for the EphA3 receptor tyrosine kinase in heart development. Dev Biol 302(1): 66-79.

Stupp R, Mason WP, van den Bent MJ, Weller M, Fisher B, Taphoorn MJ, Belanger K, Brandes AA, Marosi C, Bogdahn U, Curschmann J, Janzer RC, Ludwin SK, Gorlia T, Allgeier A, Lacombe D, Cairncross JG, Eisenhauer E, Mirimanoff RO (2005) Radiotherapy plus concomitant and adjuvant temozolomide for glioblastoma. N Engl J Med 352(10): 987-996.

Tu Y, He S, Fu J, Li G, Xu R, Lu H, Deng J (2012) Expression of EphrinB2 and EphB4 in glioma tissues correlated to the progression of glioma and the prognosis of glioblastoma patients. Clin Transl Oncol 14(3): 214-220.

Verhaak RG, Hoadley KA, Purdom E, Wang V, Qi Y, Wilkerson MD, Miller CR, Ding L, Golub T, Mesirov JP, Alexe G, Lawrence M, O'Kelly M, Tamayo P, Weir BA, Gabriel S, Winckler W, Gupta S, Jakkula L, Feiler HS, Hodgson JG, James CD, Sarkaria JN, Brennan C, Kahn A, Spellman PT, Wilson RK, Speed TP, Gray JW, Meyerson M, Getz G, Perou CM, Hayes DN (2010) Integrated genomic analysis identifies clinically relevant subtypes of glioblastoma characterized by abnormalities in PDGFRA, IDH1, EGFR, and NF1. Cancer Cell 17(1): 98-110.

Vescovi AL, Galli R, Reynolds BA (2006) Brain tumour stem cells. Nat Rev Cancer 6(6): 425-436.

Wang HU, Chen ZF, Anderson DJ (1998) Molecular distinction and angiogenic interaction between embryonic arteries and veins revealed by ephrin-B2 and its receptor Eph-B4. Cell 93(5): 741-753.

Wang LF, Fokas E, Bieker M, Rose F, Rexin P, Zhu Y, Pagenstecher A, Engenhart-Cabillic R, An HX (2008a) Increased expression of EphA2 correlates with adverse outcome in primary and recurrent glioblastoma multiforme patients. Oncol Rep 19(1): 151-156.

Wang LF, Fokas E, Juricko J, You A, Rose F, Pagenstecher A, Engenhart-Cabillic R, An HX (2008b) Increased expression of EphA7 correlates with adverse outcome in primary and recurrent glioblastoma multiforme patients. BMC Cancer 8: 79.

Wang SD, Rath P, Lal B, Richard JP, Li Y, Goodwin CR, Laterra J, Xia S (2012) EphB2 receptor controls proliferation/migration dichotomy of glioblastoma by interacting with focal adhesion kinase. Oncogene 31(50): 5132-5143.

Wen PY, Kesari S (2008) Malignant gliomas in adults. N Engl J Med 359(5): 492-507.

Wu N, Zhao X, Liu M, Liu H, Yao W, Zhang Y, Cao S, Lin X (2011) Role of microRNA-26b in glioma development and its mediated regulation on EphA2. PLoS One 6(1): e16264.

Wykosky J, Gibo DM, Debinski W (2007) A novel, potent, and specific ephrinA1-based cytotoxin against EphA2 receptor expressing tumor cells. Mol Cancer Ther 6(12 Pt 1): 3208-3218.

Wykosky J, Gibo DM, Stanton C, Debinski W (2005) EphA2 as a novel molecular marker and target in glioblastoma multiforme. Mol Cancer Res 3(10): 541-551.

Wykosky J, Gibo DM, Stanton C, Debinski W (2008a) Interleukin-13 receptor alpha 2, EphA2, and Fos-related antigen 1 as molecular denominators of high-grade astrocytomas and specific targets for combinatorial therapy. Clin Cancer Res 14(1): 199-208.

Wykosky J, Palma E, Gibo DM, Ringler S, Turner CP, Debinski W (2008b) Soluble monomeric EphrinA1 is released from tumor cells and is a functional ligand for the EphA2 receptor. Oncogene 27(58): 7260-7273.

Xiao HL, Bian XW, Li ZP, Long ZY, Wang D (2004) [Detecting protein expression of EphrinB2 ligand and its receptor EphB4 in astrocytoma using confocal laser scanning microscopy]. Ai Zheng 23(10): 1161-1165.

Yamaguchi S, Tatsumi T, Takehara T, Sasakawa A, Hikita H, Kohga K, Uemura A, Sakamori R, Ohkawa K, Hayashi N (2008) Dendritic cell-based vaccines suppress metastatic liver tumor via activation of local innate and acquired immunity. Cancer Immunol Immunother 57(12): 1861-1869.

Ying Z, Li Y, Wu J, Zhu X, Yang Y, Tian H, Li W, Hu B, Cheng SY, Li M (2013) Loss of miR-204 expression enhances glioma migration and stem cell-like phenotype. Cancer Res 73(2): 990-999.

(c) (1) (2) (2) This work is licensed under the Creative Commons Attribution-NonCommercial-Share Alike 3.0 Unported License. To view a copy of this license, visit http://creativecommons. org/licenses/by-nc-sa/3.0/ 